\title{
Mixture of Kerosene and Xylene: a Contribution to Clearing Agents
}

\author{
Mezcla de Kerosene y Xileno: una Contribución a Agentes de Aclaramiento
}

"David A. Ofusori; **A Abiodun O. Ayoka; *** Olusola A. Adeeyo \& ${ }^{* * *}$ Stephen O. Adewole

OFUSORI, D. A.; AYOKA, A. O.; ADEEYO, O. A. \& ADEWOLE, S. O. Mixture of kerosene and xylene: a contribution to clearing agents. Int. J. Morphol., 27(1):211-218, 2009.

SUMMARY: The aim of this study was to substitute costly and hazardous compound- xylene, used as clearing agent, with less costly compounds (mixture of xylene and kerosene) having less toxicity and without compromising the cellular integrity and staining characteristics of the sections. Tissues (liver and kidney) obtained from a presumable healthy adult Wistar rat, were fixed in $10 \%$ formol saline, separated in to five groups (A, B, C, D and E) and processed for light microscopic study adopting H \& E staining procedure. During the clearing section, groups A, B, C, D and E were respectively cleared in solvent 1 (xylene only), solvent 2 (70ml xylene : 30ml kerosene), solvent 3 (50ml xylene : $50 \mathrm{ml}$ kerosene), solvent 4 (30ml xylene : 70ml kerosene) and solvent 5 (kerosene only). Our result revealed that tissues in groups A, B and C were properly cleared without any morphological impairment. The staining characteristics were also observed to be very bright. Groups D and E however presented poor staining intensity with reduced cellular details. Semistained transparent patches were also noticed. It is inferred from the present investigation that a mixture of xylene and kerosene could be employed in the clearing of tissues only at the prescribed ratio i.e. solvent 2 and solvent 3 without posing any health risk or compromising the cellular integrity.

KEY WORDS: Xylene; Kerosene; Clearing agent; Liver; Kidney.

\section{INTRODUCTION}

Tissue processing in histology and cytology is a physical process that involves chemical solutions reacting with biological specimens. Specimens from biopsies and autopsies require processing. These processes require four different procedures: (a) Fixation- The purpose of fixation is to preserve tissues permanently in as life-like a state as possible. Fixation should be carried out as soon as possible after removal of the tissues (in the case of surgical pathology) or soon after death (with autopsy) to prevent autolysis. There is no perfect fixative. Therefore, varieties of fixatives are available for use, depending on the type of tissue present and features to be demonstrated. The most commonly used chemical solution is formalin (Drury \& Wallington, 1967). (b) Dehydration- Since the ultimate purpose of tissue specimen treatment is to infiltrate the tissue sample in paraffin, and since water and paraffin are not miscible, the sample must be dehydrated after the fixation step. This is usually achieved by subjecting the tissue sample to increasing concentrations of alcohols (Drury \& Wallington). (c) Clearing- It is the process of replacing the dehydrant with a substance that will be miscible with the embedding medium (paraffin). The term "clearing" comes from the fact that the clearing agents often have the same refractive index as proteins. As a result, when the tissue is completely infiltrated with the clearing agent, it becomes translucent. This change in appearance is often used as an indication of the effectiveness or completeness of the clearing process (Drury \& Wallington). The chemical solution (clearing agent) most commonly used is xylene.

Unfortunately, xylene is considered to be toxic although most histological processing laboratories use xylene on a daily basis. (d) Infiltration- The fourth and final step in the tissue sample treatment is infiltrating the sample, usually

\footnotetext{
* Department of Anatomy and Cell Biology, Faculty of Basic Medical Sciences, Obafemi Awolowo University, Ile-Ife, Osun-State, Nigeria.

** Department of Physiological Sciences, Faculty of Basic Medical Sciences, Obafemi Awolowo University, Ile-Ife, Osun-State, Nigeria.

**** Department of Human Anatomy, Faculty of Basic Medical Sciences, Ladoke Akintola University of Technology, Ogbomoso, Oyo-State, Nigeria.
} 
with paraffin wax. In this step the cleared tissue samples are placed into paraffin heated to a few degrees above its melting temperature. Several changes of paraffin may be required to remove the residual xylene so that the tissue is completely infiltrated with the molten paraffin. The aftermath of such processing is a sample that has been preserved, infiltrated and embedded with paraffin. Once all these have been done, it is then sectioned on a microtome.

Xylene is a type of clearing agent that reasonably works well for short-term clearing of small tissue blocks. Long-term immersion of tissue in xylene results in tissue distortions. Toluene works well, and is more tolerant of small amounts of water left in the tissues, but is 3 times more expensive than xylene. Chloroform used to be used, but is a health hazard, and is slow (Drury \& Wallington). Methyl salicylate is rarely used because it is expensive, but it smells nice (it is oil of wintergreen).

There are newer clearing agents available for use. Many of them are based on limolene, a volatile oil found in citrus peels. Another uses long chain aliphatic hydrocarbons (Clearite). Although they represent less of a health hazard, they are less forgiving with poorly fixed, dehydrated, or sectioned tissues (Dapson \& Dapton, 1995).

Kerosene widely used in kerosene lamps and lanterns, is a thin, clear liquid formed from hydrocarbons, with density of $0.78-0.81 \mathrm{~g} / \mathrm{cm}^{3}$. Kerosene is obtained from the fractional distillation of petroleum between $150{ }^{\circ} \mathrm{C}$ and $275^{\circ} \mathrm{C}$, resulting in a mixture of carbon chains containing $12-15$ carbon atoms. It is sometimes spelt as kerosine in scientific and industrial usage. In Nigeria, kerosene can be readily bought at any filling stations.

Its use as a cooking fuel is mostly restricted to some portable stoves. Kerosene, a flammable hydrocarbon liquid is widely used in Nigeria and India as fuel for domestic activities. In countries such as Nigeria, kerosene is the main fuel used for cooking, especially by the poor. Kerosene stoves have replaced the traditional wood-based cooking appliances that are unhealthy and inefficient. Kerosene has been used to treat pools of standing water to prevent mosquitoes from breeding. It is used as a solvent and in conjunction with cutting oil as a thread cutting and reaming lubricant.

Kerosene is not considered to be carcinogenic or teratogenic as observed in xylene (Khattak et al., 1999; Risher \& Rhodes, 1995). The acute health risks involved in handling and using kerosene are minimal, provided that the product(s) are used in accordance with current safety practices (Henry, 1998). The most common health effect associated with chronic / repeated kerosene exposure is dermatitis (Ritchie et al., 2003).

Literature search revealed that some organic compounds have been discovered to pose serious reproductive problems (Dapson, 2000). Very recently, a reproductive study of workers exposed to workplace solvents, such as xylene have health risk problem which in some cases, also put the fetus at risk (Dapson \& Dapson; Khattak et $a l$.). Mixture of the two solvents (kerosene and xylene) may reduce the risk associated with xylene when used alone.

It is therefore worthwhile to substitute costly and hazardous compound- xylene with a less toxic compound without impairing the morphology and staining characteristics of the sections.

\section{MATERIAL AND METHOD}

Preparation and Mixture of solvents. The xylene used was a product of Sigma (USA), while the kerosene was got from Nigerian National Petroleum Corporation (NNPC) Mega filling station Akure, Ondo-State, Nigeria. The two compounds were mixed in the following ratios:

Absolute xylene (solvent 1), 70 xylene : 30 kerosene (solvent 2), 50 xylene : 50 kerosene (solvent 3), 30 xylene : 70 kerosene (solvent 4 ) and absolute kerosene (solvent 5).

Experimental design and Tissue collection. Sample of tissues (liver and kidney) were harvested from a presumably healthy adult Wistar rats (Rattus norvegicus) trimmed and washed in physiological saline before fixing in $10 \%$ formol saline. After 48 hours, the fixed tissues were re-trimmed in to smaller bits of nearly equal sizes and separated in to five groups (A, B, C, D and E).

Histological procedure. Each of the groups was processed for light microscopic study. These included dehydration through graded ethanol, clearing, infilteration in paraffin wax for 2 hours at $56^{\circ} \mathrm{C}$ and embedding of the tissues in paraffin wax for 48 hours. Sections were obtained on a rotary microtome at $5 \mu \mathrm{m}$ thickness. The sections were finally subjected to haematoxylin and eosin (H \& E) staining procedure. During the clearing section, groups A, B, C, D and E were, respectively, cleared in solvents 1, 2, 3,4 and 5. The duration for clearing was one and two hours for each group. The histological procedures for all the groups were carried out under the same laboratory condition. 


\section{RESULTS}

Blocks of Tissue and Sectioning. The embedded blocks of tissue in groups A, B and C were carefully observed. The tissues were properly embedded and in good shape without any form of depression of the tissues in the embedding paraffin wax. This was however, not the same for groups D and $\mathrm{E}$ as the tissues were opaque in appearance and depressed in the embedding paraffin wax. This eventually affected the smooth and proper sectioning of the tissues. Some of the serial sections got from groups D and E wrinkled excessively but the initial flattering of these sections on the slides with $10 \%$ alcohol before transferring to warm water removes the wrinkles.

Histological Sections. The sections obtained from groups A, B and C, demonstrated a good outline (Figs. 1, 2 and 3). The cellular details were well preserved and the staining intensity was uniform without any semi-stained transparent patches as observed in groups $\mathrm{D}$ and $\mathrm{E}$. There was a reduction in the cellular details as well as staining intensity on the sections obtained in groups D and E (Figs. 4 and 5). This observation was pronounced in group $\mathrm{E}$.

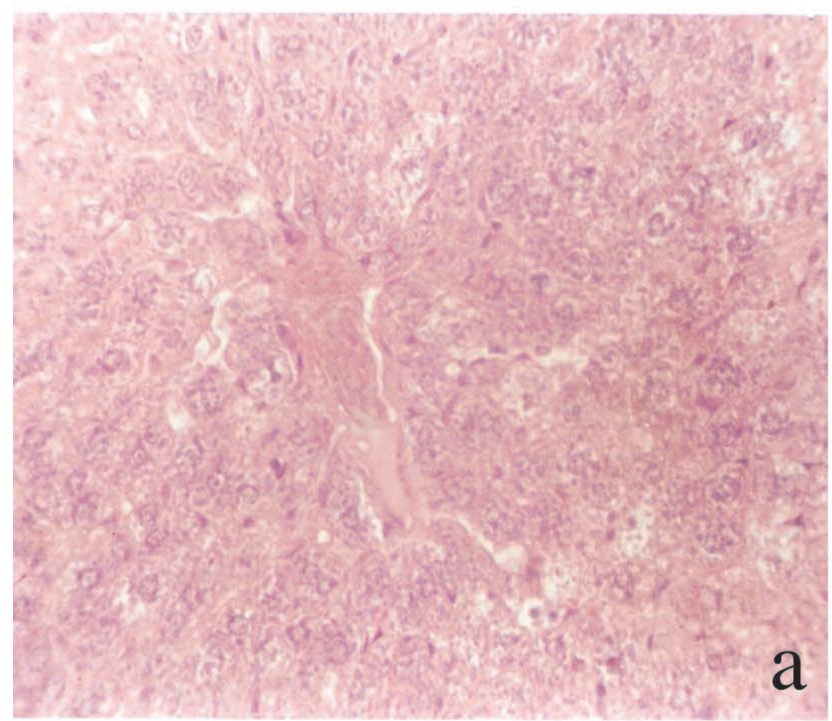

Fig. 1. Photomicrograph of group A (cleared in xylene only) showing: (a) Liver, cleared for 1hour; (b) liver, cleared for 2 hours; (c) kidney, cleared for 1 hour and (d) kidney, cleared for 2 hours H \& E x 400 .
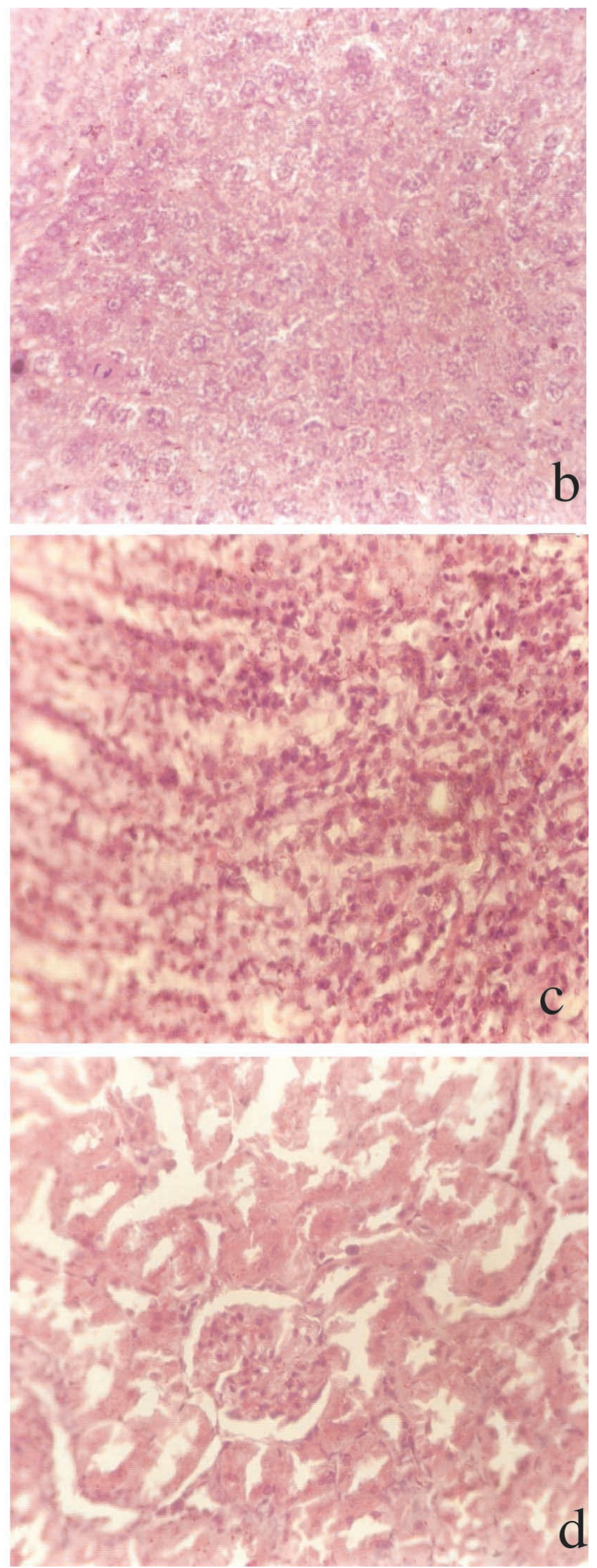

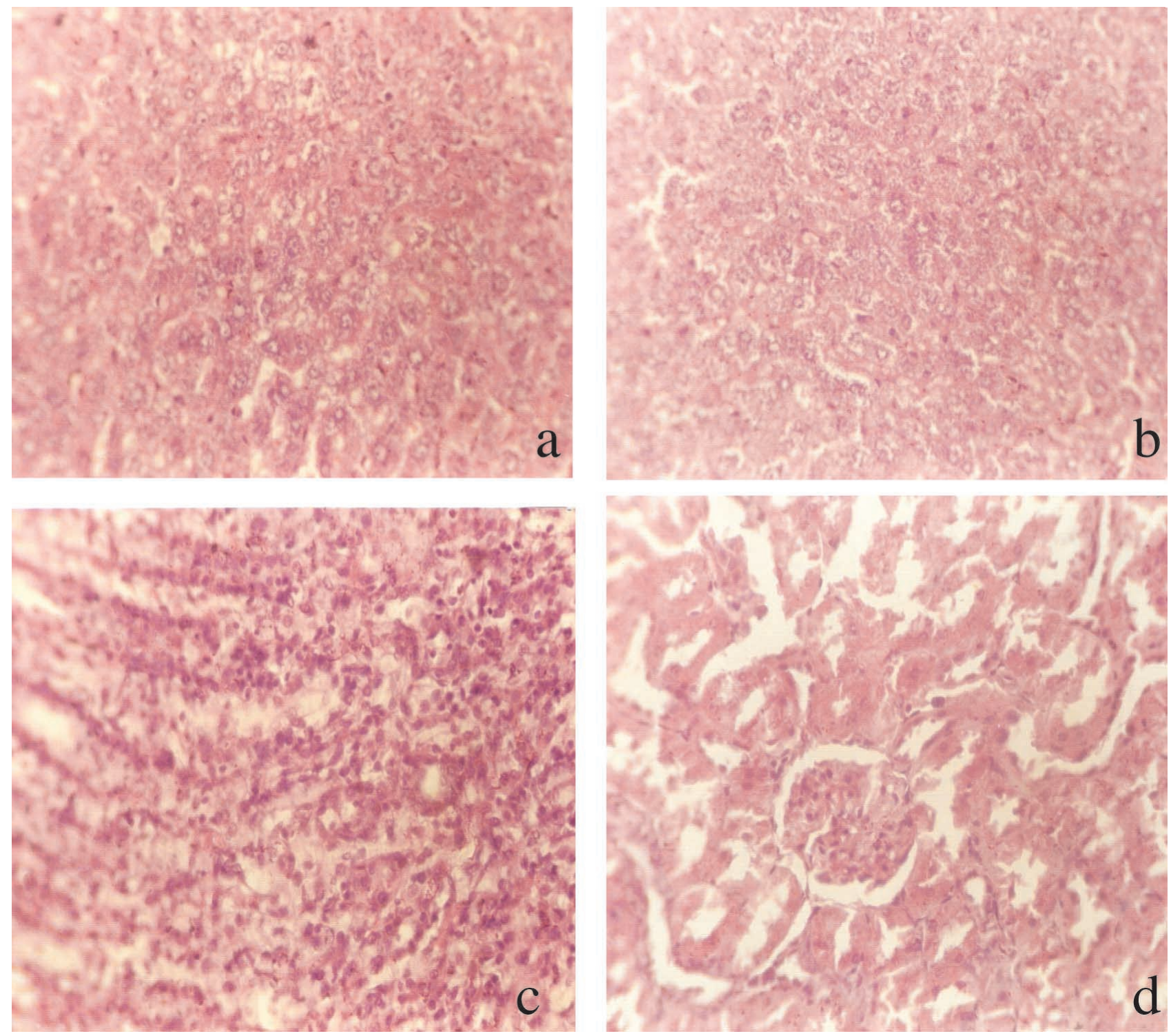

Fig. 2. Photomicrograph of group B (cleared in 70ml xylene : $30 \mathrm{ml}$ kerosene) showing (a) liver, cleared for 1 hour; (b) Liver, cleared for 2 hours; (c) Kidney, cleared for 1 hour and (d) Kidney, cleared for 2 hours. H \& E x400.

\section{DISCUSSION}

Blocks of Tissue and Sectioning. The observed depression of tissues in the embedding paraffin wax for groups D and $\mathrm{E}$ is an indication of improper clearing of the tissues. The tissues were also observed to be opaque in contrast to a translucent appearance in groups $\mathrm{A}, \mathrm{B}$ and $\mathrm{C}$ indicative of improper clearing. Opaqueness of tissues after clearing is evidence that the tissues were not properly cleared (Drury \& Wallington). This might be related to the high ratio of kerosene to xylene as this observation was pronounced in group E which was cleared in kerosene only. The difficulty encountered during sectioning may be due to hardness of the tissues imposed by high concentration of kerosene. It can be inferred therefore that increased concentration of kerosene affects the proper clearing (for a period of one and two hours) as well as sectioning of tissue blocks. Further studies prolonging the duration for clearing in solvents 4 and 5 can be employed. This will provide useful information on the proper application. 

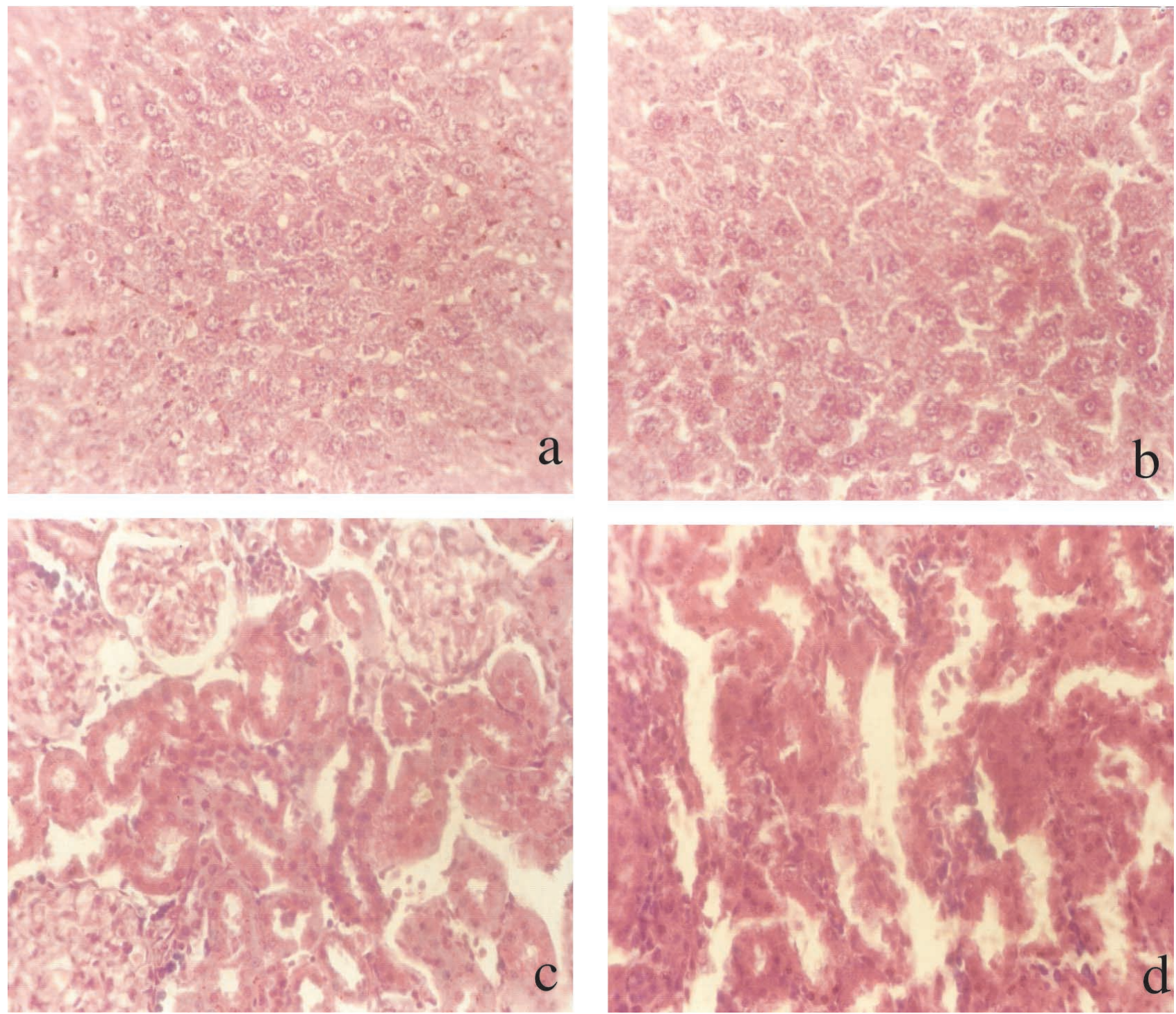

Fig. 3. Photomicrograph of group C (cleared in 50ml xylene : $50 \mathrm{ml}$ kerosene) showing (a) liver, cleared for 1 hour; (b) Liver, cleared for 2 hours; (c) Kidney, cleared for 1 hour and (d) Kidney, cleared for 2 hours H \& E x400.

Histological Sections. Our investigation has shown that a mixture of xylene and kerosene at a ratio of $70: 30$ and 50 : 50 is a good substitute for absolute xylene in histology and cytology. It is safer and a more preferable alternative to xylene. In the alternative, kerosene is cheaper and as such, this investigation has provided a cost effective means of clearing tissues without compromising the cellular integrity. Xylene is known for its carcinogenic (Risher \& Rhodes) and teratogenic (Khattak et al.) potential. Kerosene has also been reported to cause dermatitis under prolonged exposure (Ritchie et al.). The mixture of the two solvents (kerosene and xylene) is however expected to reduce these negative influences on human vis-à-vis qualitative and efficient clearing of the tissues.
The good outline of the sections from groups A, B and C (Figs. 1, 2 and 3) has shown that a mixture of xylene and kerosene at a ratio for solvents 2 and 3 is a better alternative to xylene alone. These observations were not dependent on the duration of clearing. That is to say, the tissues cleared for one hour and two hours present the same cellular details without any morphological alterations. Sections of the liver for groups $\mathrm{A}, \mathrm{B}$ and $\mathrm{C}$ were characterized by hepatocytes, forming flat anastomosing plates. The irregular hexagonal lobule defined by portal tracts and sparse collagenous tissue were also evident (Figs. 1, 2 and 3) similar to the observations of Heath et al. (1999a). These observations were not so prominent in groups $\mathrm{D}$ and $\mathrm{E}$ as a result of semi-stained transparent patches which characterized the sections (Figs. 4 and 5). 

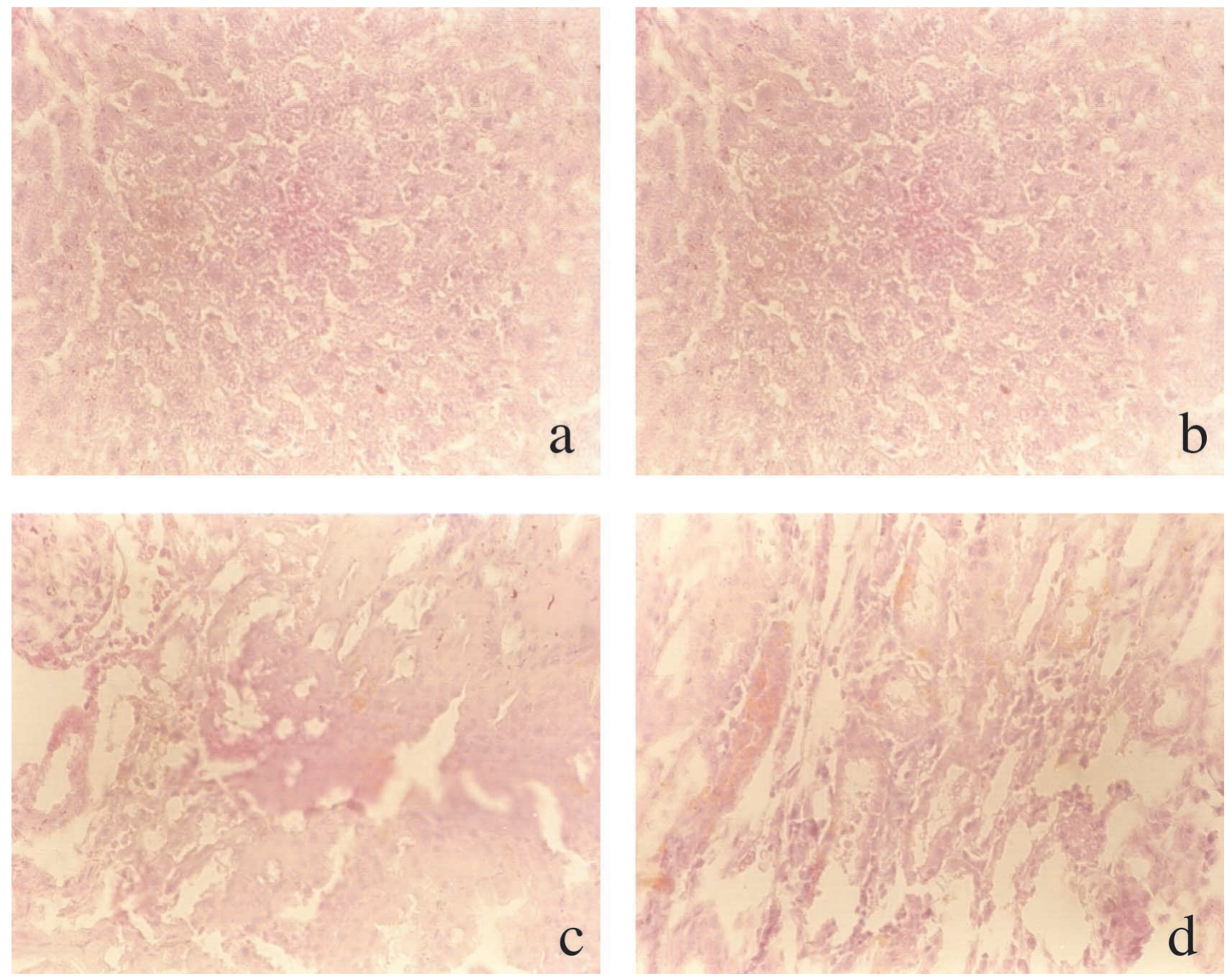

Fig. 4. Photomicrograph of group D (cleared in 30ml xylene : 70ml kerosene) showing (a) liver, cleared for 1 hour (b); liver, cleared for 2 hours (c) kidney, cleared for 1 hour and (d) kidney, cleared for 2 hours. Note the reduced staining intensity and semi-stained transparent patches. H \& E x400.

Sections of the kidney for groups A, B and C were also characterized by prominent glomerulus and convolutions of the proximal convoluted tubules (Figs. 1,2 and 3) which are inline with the observations of Heath et al. (1999b). The same was observed from sections in groups D and $\mathrm{E}$ but partly obscured by the semi-stained transparent patches (Figs. 4 and 5).

For groups D and E, the clearance of the tissues was dependent on the duration of clearing. Sections from tissues cleared for two hours were better in outline and have greater affinity for stain than those cleared for one hour (Figs. 4 and 5). The constituent of kerosene that brought about the improper clearing (for a period of one and two hours) is yet to be discovered and still been investigated. We however suggest from our observation that prolonging the clearing period might give a better result.
Adopting our newly discovered clearing agent formula (solvent 2 and 3) will reduce the carcinogenic and teratogenic effect of xylene (Risher \& Rhodes; Khattak et $a l$.). This will also increase the availability of clearing agent in Basic Medical research in developing countries like Nigeria where research is of utmost priority. Our observation did not only confirm a mixture of xylene and kerosene as a solvent and clearing agent, but also confirm its ability to dissolve paraffin waxes and glues at a shortest possible time.

It can be inferred from the present investigation that a mixture of xylene and kerosene could be employed in the clearing of tissues only at the prescribed ratio i.e. solvent 2 and solvent 3 without posing any health risk or compromising the cellular integrity. 

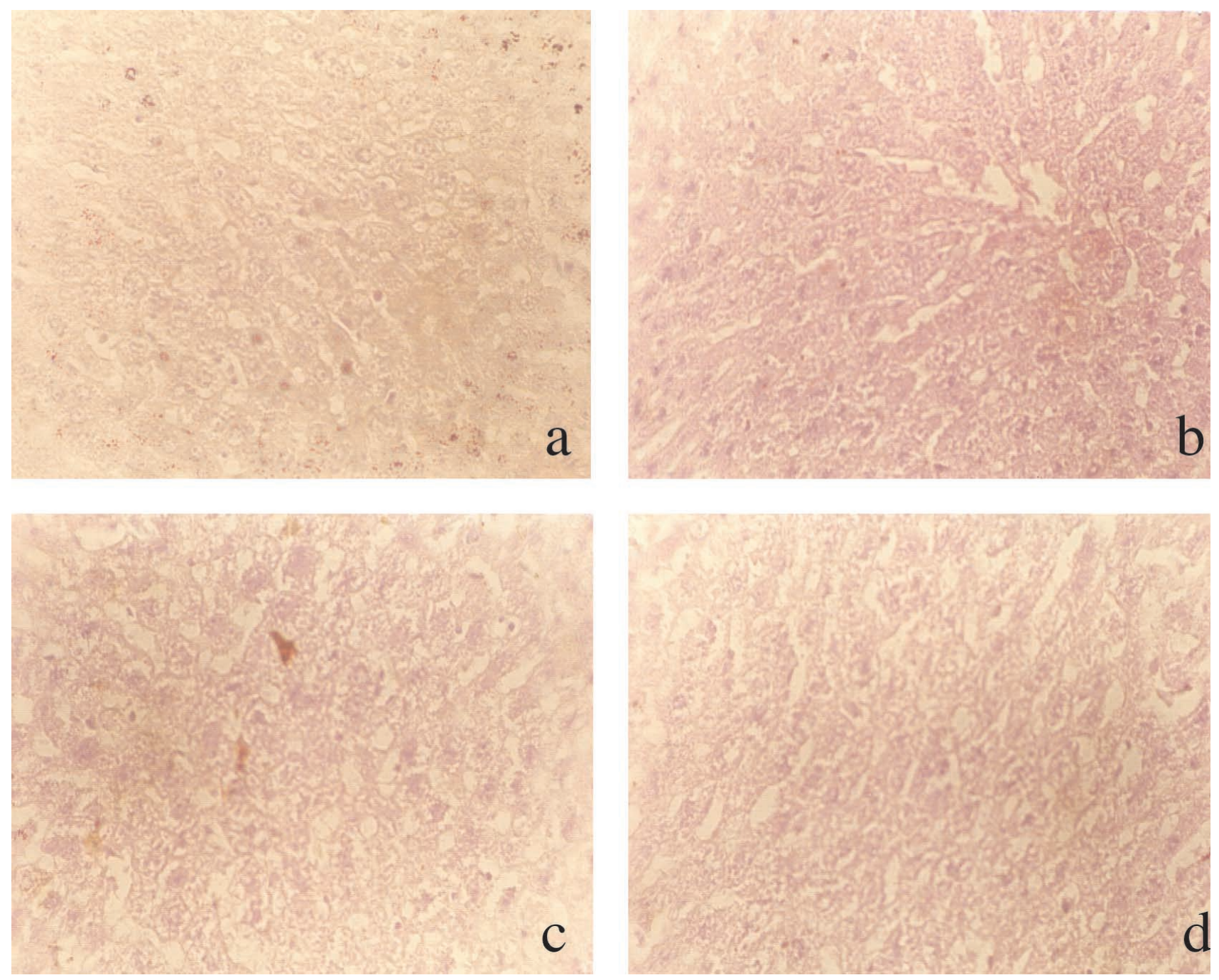

Fig. 5. Photomicrograph of group E (cleared in kerosene only) showing (a) Liver, cleared for $1 \mathrm{~h}$ (b) Liver, cleared for $2 \mathrm{~h}$ (c) Kidney, cleared for $1 \mathrm{~h}$ (d) Kidney, cleared for $2 \mathrm{~h}$. Note the reduced staining intensity and the semi-stained transparent patches. H \& E x 400 .

ACKNOWLEDGMENT. The authors appreciate the technical assistance of E. Gbela of the Department of Morbid Anatomy and Forensic Medicine, Obafemi Awolowo University, Ile-Ife, Nigeria.

OFUSORI, D. A.; AYOKA, A. O.; ADEEYO, O. A. \& ADEWOLE, S. O. Mezcla de kerosene y xileno: Una contribución a agentes de aclaramiento. Int. J. Morphol., 27(1):211-218, 2009.

RESUMEN: El objetivo de este estudio fue el de sustituir el costoso y peligroso compuesto xileno, utilizado como agente de aclaramiento, por un compuesto menos costoso (mezcla de kerosene y xileno), con menor toxicidad y sin comprometer la integridad celular ni las características de tinción de las secciones. Los tejidos (hígado y riñón) fueron obtenidos a partir de una rata Wistar adulta presumiblemente sana, los que fueron fijados en solución de formalina salina al 10\%, y separadas en cinco grupos (A, B, C, D y
E) y tratadas para estudio con microscópico de luz, con tinción H \& E. Durante el aclaramiento de las secciones histológicas, los grupos A, B, C, D y E, fueron, respectivamente, aclarados con el disolvente 1 (sólo xileno), solvente 2 (70ml de xileno: $30 \mathrm{ml}$ Kerosene), solvente 3 (50ml de xileno: $50 \mathrm{ml}$ Kerosene), solvente 4 (30ml xileno: $70 \mathrm{ml}$ kerosene) y solvente 5 (sólo el kerosene). Los resultados revelaron que los tejidos de los grupos A, B y C fueron aclarados correctamente sin alteraciones morfológicas. En la tinción también se observó como característica, ser muy brillante. Los grupos D y E, sin embargo presentaron una tinción de pobre intensidad con la reducción de los detalles celulares. Zonas con manchas semitransparentes también fueron observadas. Se infiere que una mezcla de xileno y kerosene podría ser empleado en el aclaramiento de los tejidos, sólo prescrito en la proporción del solvente 2 y 3 , sin suponer ningún riesgo para la salud o comprometer la integridad celular.

PALABRAS CLAVE: Xileno; Kerosene; Agente aclarador; Hígado; Riñón. 
OFUSORI, D. A.; AYOKA, A. O.; ADEEYO, O. A. \& ADEWOLE, S. O. Mixture of kerosene and xylene: a contribution to clearing agents. Int. J. Morphol., 27(1):211-218, 2009.

\section{REFERENCES}

Dapson, J. N. \& Dapson, R. W. Hazardous materials in the histopthology laboratory: regulations, risks, handling and disposal. $3^{\text {rd }}$ edition. Battle Creek, MI. Anatech Ltd., 1995.

Dapson, J. N. Organic solvents as reproductive hazards. Mikro-Graf., 29(2):1-4, 2000.

Drury, R. A. B. \& Wallington, E. A. Carleton's histological. technique. $4^{\text {th }}$ ed. New York, Oxford University Press, 1967.

Heath, J. W.; Young, B. \& Burkitt, H. G. Liver and pancreas. In: Wheater's functional histology. (Stevenson, R. Ed). $3^{\text {rd }}$ ed. London, UK, Churchill Livingstone, 1999a. pp.271-81.

Heath, J. W.; Young, B. \& Burkitt, H. G. Urinary System In: Wheater's functional histology. (Stevenson, R. Ed). $3^{\text {rd }}$ ed. London, UK, Churchill Livingstone, 1999b. pp.282303.

Henry, J. A. Composition and toxicity of petroleum products and their additives. Hum. Exp. Toxicol., 17(2):111-23, 1998.

Khattak, S.; K-Moghtader, G.; McMartin, K.; Barrera, M.; Kennedy, D. \& Koren, G. Pregnancy outcome following gestational exposure to organic solvents. J. Am. Med. Assoc., 281(12):1106-9, 1999.

Risher, J. F. \& Rhodes, S. W. Toxicological profiles for fuel oils. US Department of Health and Human Services, 1995.

Ritchie, G.; Still, K.; Rossi, J.; Bekkedal, M.; Bobb, A. \& Arfsten, D. Biological and health effects of exposure to kerosene-based jet fuels and performance additives. $J$. Toxicol. Environ. Health B. Crit. Rev., 6(4):357-451, 2003.
Correspondence to:

Ofusori David A.

Department of Anatomy and Cell Biology

Faculty of Basic Medical Sciences

Obafemi Awolowo University

NIGERIA

Tel: +234-803-445-5715

Email: davidofus234@yahoo.com

Received: 11-06-2008

Accepted: 09-10-2008 